\title{
The ghost-rock of the Chansin quarry (Belgium) - A remarkable example of pseudogallery
}

\author{
Caroline DUBOIS ${ }^{1} \&$ Yves QUINIF²*
}

${ }^{1}$ Department of Geology \& Applied Geology, Faculty of Engineering, University of Mons, Belgium.

${ }^{2}$ Professor emeritus, University of Mons, Belgium; yves.quinif2@gmail.com.

"corresponding author.

ABSTRACT. In the Chansin quarry (Belgium), a horizontal karstic gallery which seems to be totally filled has been discovered. The study of this filling shows that it is composed of a residual alterite from the bedrock. The ghost-rock karstification has stopped just after the first phase of this karstogenesis. The residual alterite is still present, without significant geometrical modification. The transition between the unaltered bedrock and the ghost-rock is very clear. We present the characteristics of this ghost-rock which is here regarded as a typical example of a pseudo-gallery and act as a reference for further definition.

KEYWORDS: ghost-rock, pseudogallery, residual alterite mineralogy.

RÉSUMÉ. Le fantôme de roche de la carrière de Chansin (Belgique) - Un exemple remarquable de pseudo-galerie. La carrière de Chansin (Belgique) a révélé une forme karstique horizontale qui semble être totalement colmatée. Une étude de ce colmatage prouve qu'il est constitué d'altérite résiduelle provenant de l'altération de la roche mère. La fantômisation s'est arrêtée juste après cette première phase d'altération isovolumétrique. L'altérite est toujours présente, sans modification géométrique importante. La transition entre la roche mère et le fantôme de roche est très nette. Nous présentons les caractéristiques de ce fantôme de roche qui est considéré ici comme un exemple typique de pseudogalerie et sert de référence pour une définition plus détaillée.

MOTS-CLÉS : fantôme de roche, pseudogalerie, minéralogie de l'altérite résiduelle.

\section{Introduction}

Ghost-rock karstification includes a first phase of partial dissolution of the bedrock with elimination of solutes and formation of isalterite (Dubois et al., 2014; Quinif, 2010; Vergari, 1998). This first stage of the phenomenon occurs during a biostasy phase characterized by the combined presence of acidic water, an initial permeability in the bedrock allowing a hydraulic transmissivity and the weakness of the hydrodynamic potential (Quinif et al., 2014). The result consists of a series of subterranean bodies in contact with the surface or not where volumes of bedrock are replaced by a very porous ghost-rock but having retained the initial structures such as stratification. This alterite settles down and is mechanically eroded during a second phase when a hydrodynamic potential develops, resulting in the creation of speleological caves (Quinif, 2014).

In 'mature' karsts, the difficulty is to demonstrate the first phase of alteration and, as such, to find volumes still filled with their residual alterite, since the cave undergoes intense fluvial erosion. Ghost-rocks witnessing this first phase are often observed in quarries (Quinif et al., 1993; Havron et al., 2007, Rowberry et al., 2018). Chansin quarry, in the province of Namur (Belgium), provides a good example of a ghost-rock with a gallery-like shape.

\section{Location and geology}

The Chansin quarry (also known as Nutons quarry) is an excavation located on the right bank of the Bocq River (Fig. 1), exploiting Tournaisian (Lower Carboniferous) limestones. The ghost-rock was exposed on the upper floor of the quarry but the exploitation condemned the studied pseudo-gallery to disappear.

Several Tournaisian formations (Fig. 2) are exposed in the quarry where they display a moderate northward dip. This dip $\left(\mathrm{N} 80^{\circ} \mathrm{E}-35^{\circ} \mathrm{N}\right)$ permits to see, from bottom to top (i) the Hastière Formation composed of crinoidal limestones with argillaceous and calcareous clay beds, (ii) the shales of the Pont d'Arcole Formation, (iii) the Landelies Formation with its crinoidal limestones, (iv) the Yvoir Formation consisting of limestones with cherts (Poty et al., 2001). At the base of this formation occurs the Hun Member composed of sandy limestones with thin shaly intercalations (Poty et al., 2001). The ghost-rock is developed in this member. Ghost-rocks and karsts have not been observed in the underlying limestones.

The quarry wall being parallel to the direction of the strata, the latter appear with an apparent sub-horizontal dip. The "ghost gallery" is cut lengthwise and thus appears outcropping like an irregular rectangle that follows the stratification.

\section{Description of the shape}

The irregular front of the quarry cuts the ghost-rock. This ghostrock has a gallery-like shape cut parallel to its length. This gallery is totally composed of residual alterite, as shown by the lithologic survey (see section 4).

Figure 3 displays the entire ghost-rock before the survey works, while Figure 4 shows the central part of the pseudogallery. The stratification is similar to that of the bedrock. The folded shapes are due to settlements and in-situ movements. The deformation of the residual alterite, which might be an apparent end of the pseudogallery, probably, comes from an elbow in this pseudogallery, cut by quarrying. We also distinguish little weathered blocks in the deformed part on the right.

Three sections were studied. The first two were chosen on either side of a central pillar of intact bedrock (Fig. 4). The third one is wider and aims to describe a peculiar weathered stratum.

\section{Ghost-rock lithology}

The porosity of the ghost-rock is very large, due to the complete decarbonation. Residual alterite consists of microcrystalline silica ("tripoli" facies) or clays, remnants of the non-carbonated part of the bedrock.

\subsection{Section 1}

This section no longer shows any intact lithology of the bedrock. The entire series is a vertical succession of crumbly lithologies, ranging from sandy to clay facies (Fig. 5). The different lithologies are the following.

\subsubsection{Sand}

Yellow to white, it forms the basis of the series. It is crossed with ferruginous strips. No microstratification is visible. The granulometric analysis shows no sorting (Fig. 6).

\subsubsection{Tripoli}

It is a white rock, very porous, with a low specific density and no reaction to acid. This formation is well known in the limestones of the Tournaisis area, within the large quarries of Antoing (Hennebert \& Doremus, 1997). This is residual microcrystalline silica after dissolution of all the carbonates.

\subsubsection{Clay facies}

Brown in colour, this lithology presents the characteristics of non-hardened clay rock, notably by its layered appearance. 

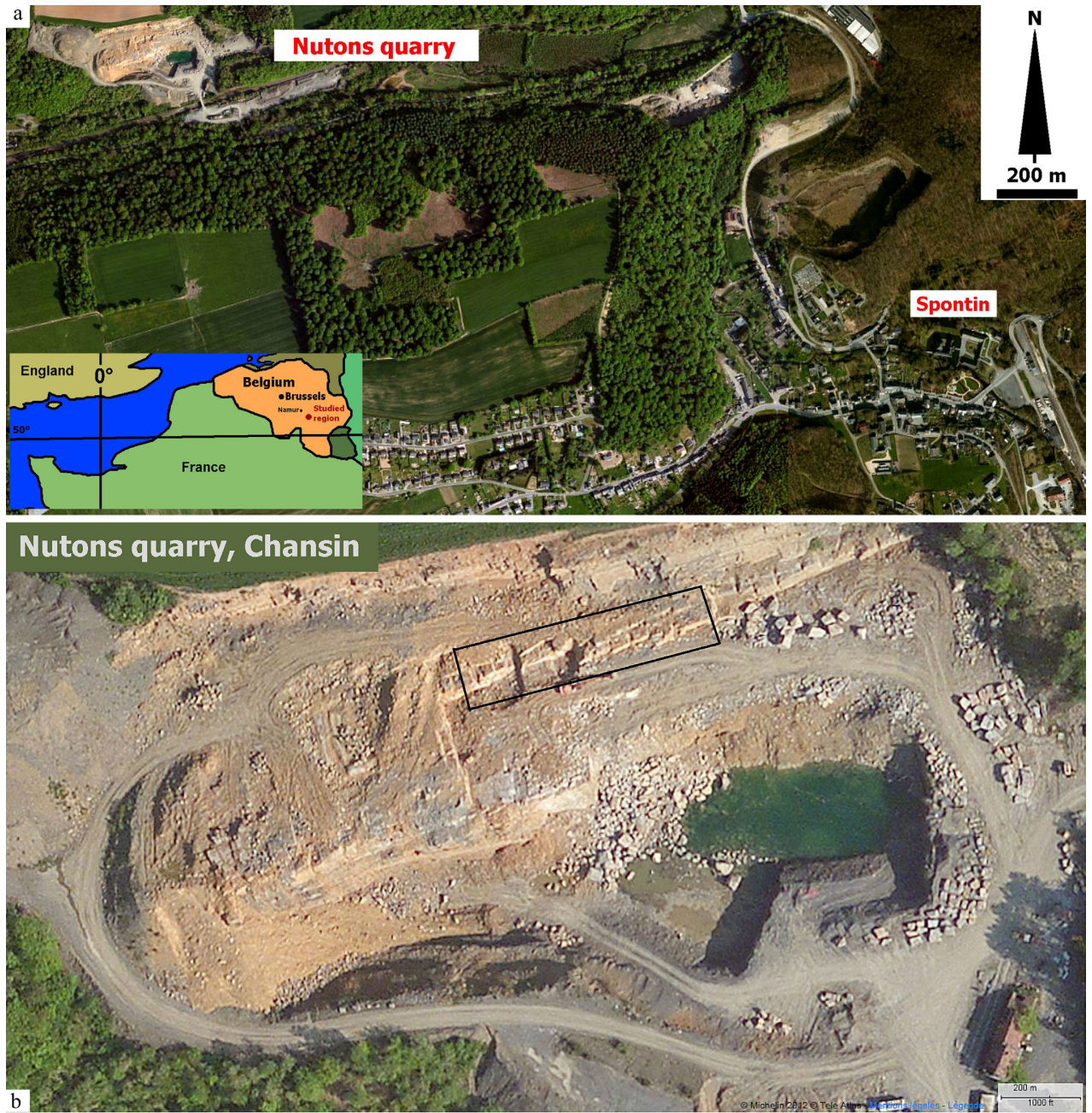

Figure 1. a. Location of the studied site. b. Location of the ghost-rock in the quarry. The ghost-rock is at the bottom of the last bearing. It is a horizontal pseudogallery type. It shows a succession of strata corresponding to the weathered bedrock. It is dug in the Yvoir Formation, in the Hun Member North at the top. Images from Google Earth.
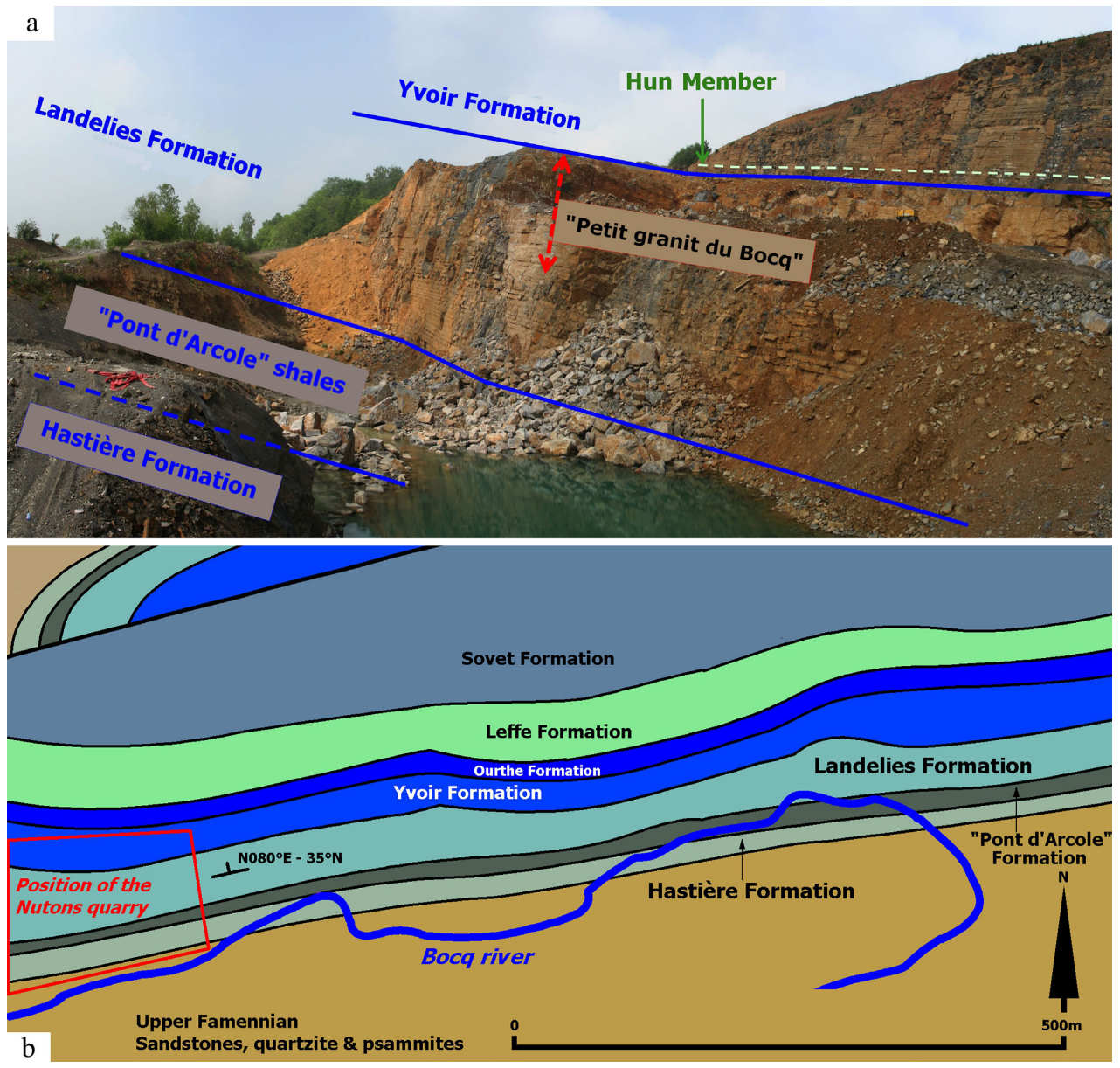

Figure 2. a. Lithostratigraphy of the quarry (Poty et al., 2011) (state of outcrop in 2010). The ghost-rock situates on the bearing where the Hun Member outcrops. View to the NW. b. Geological map of the site (following J.-M. Marion). 


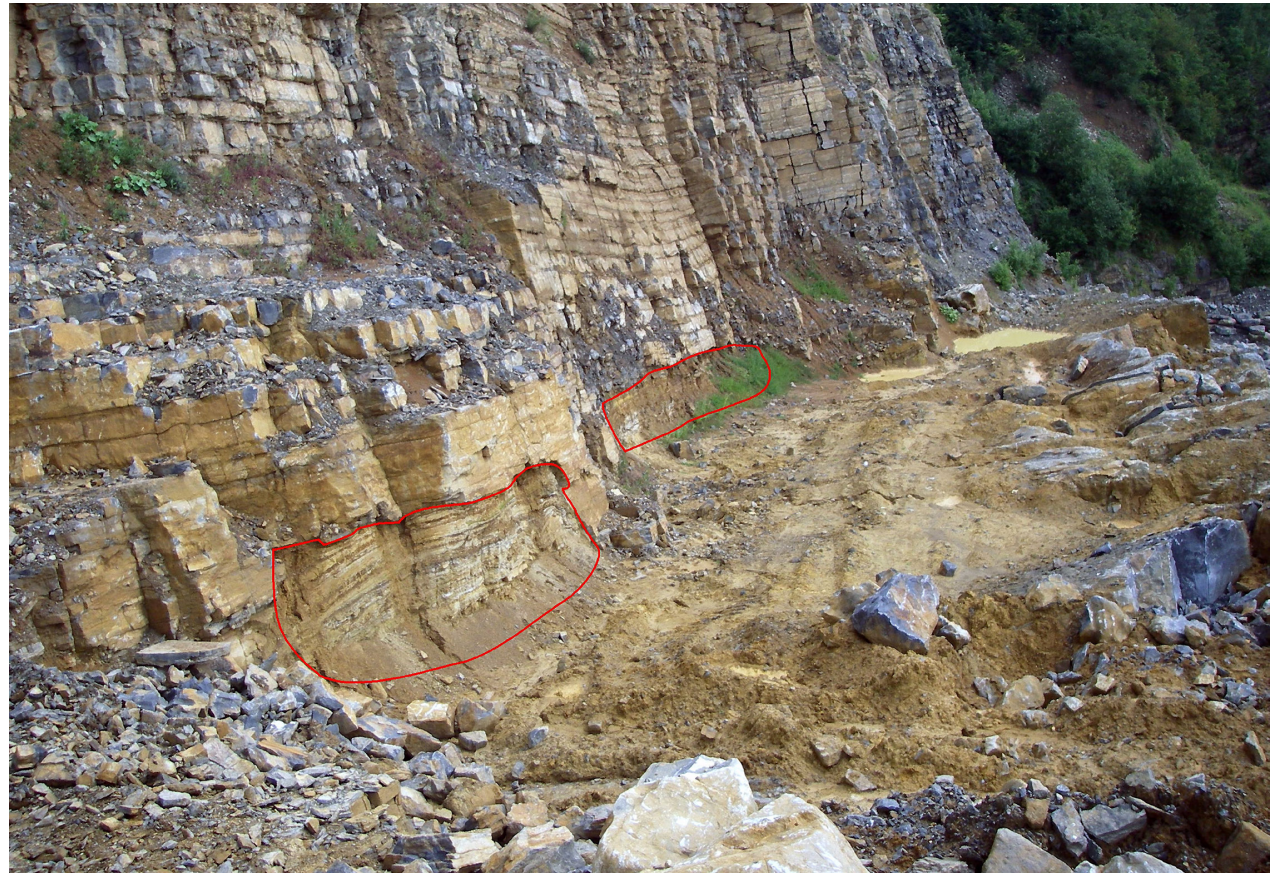

Figure 3. Outcrop of the ghost-rock circled by the two red lines before the survey works. View to the NW.

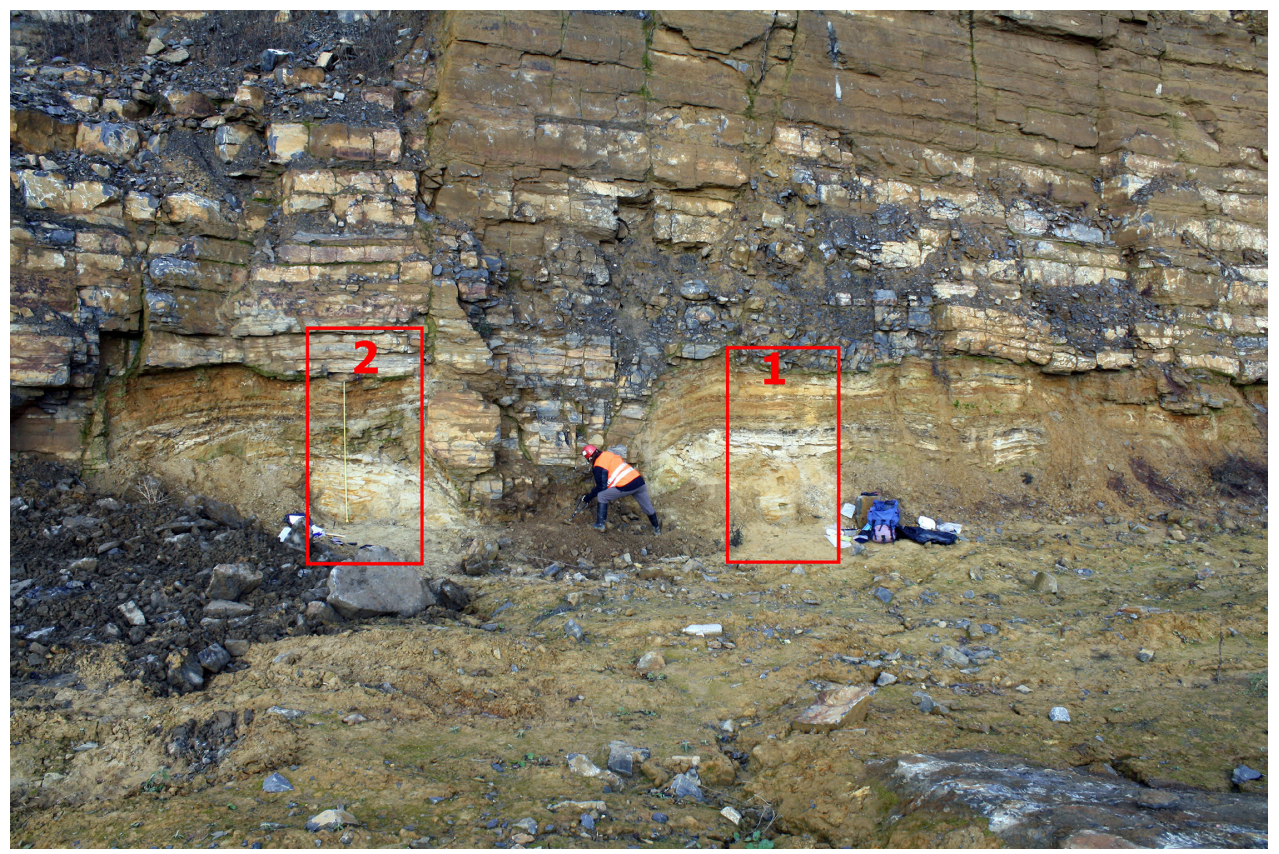

Figure 4. Location of sections 1 and 2. They were selected on both sides of an intact bedrock pillar for comparison. View to the $S$.

\subsection{Section 2}

Contrary to the first section, this second one displays more or less weathered bedrock associated with totally weathered facies (Fig. 7). The section also displays the progressive change from non-weathered bedrock to ghost-rock. The occurrence of residual calcite in these lithologies is demonstrated by their reaction to hydrochloric acid.

\section{Transition from bedrock to residual alterite}

At several places, we can observe a lateral transition within the same stratum between the bedrock and the weathered rock. Figure 8 illustrates the transition from the unaltered or slightly weathered limestone beds to ghost-rock. Although the block still gives a clear sound to the hammer, the lateral lithology can be penetrated by the knife.

This is the section 3 that shows the most beautiful example of lateral variation. It is to the right of section 1 (Figs $9 \& 10$ ). Over several metres, the transformation from pieces of intact stratum to the crumbly alterite can be followed. The stratification can easily be followed even where the stratum is deeply weathered. The seemingly intact parts of the bedrock are compact and resistant (clear hammer sound) but the most weathered parts have become crumbly and can easily be removed with a knife.

\section{Mineralogical analysis}

To determine the nature of the samples, we opted for an X-ray powder analysis. The diffractometer operated at $30 \mathrm{kV}$ and 40 $\mathrm{mA}$, with a copper X-ray tube (1.541 $\AA$ wavelength). Scanning parameters were: $0.02{ }^{\circ} 2 \Theta$ steps with $0.5 \mathrm{~s}$ integration time per step and a scanning range of $4-70^{\circ}$. A variable slit was used and the sample was continuously rotated to minimize orientation effects. The results are presented in Table 1.

Sample NUO2, undisturbed bedrock taken from the pillar separating sections 1 and 2 in front of sample NUO1, consists of calcite, quartz and clay. It is a clayey-sandy limestone, as shown on the geological map and as confirmed by calcimetry (Table 1). Similar results are found for samples NUO7b and NUO11b. The altered samples contain no or nearly no calcite as also confirmed by calcimetry. 

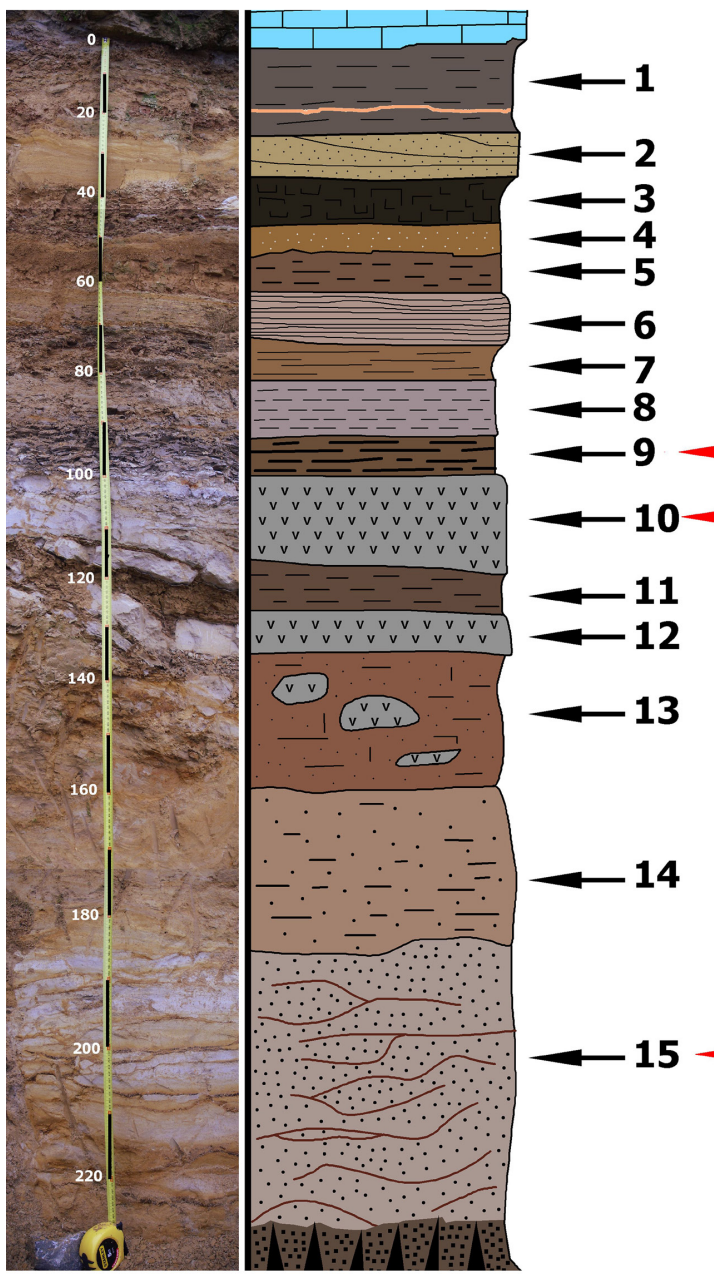

14

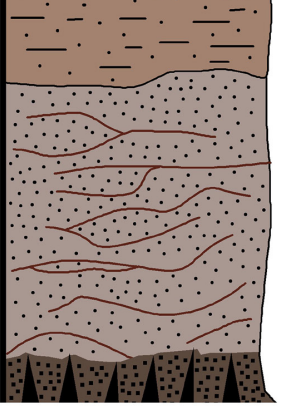

\section{(1)}

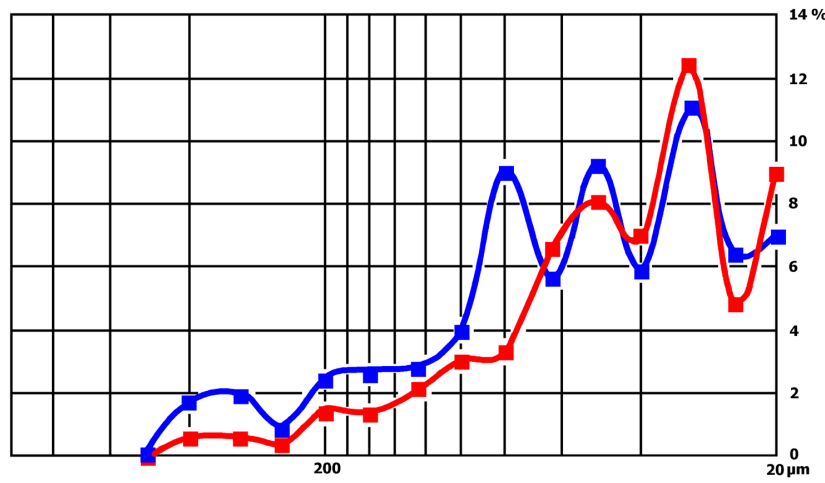

Figure 6. Granulometric curves of the sandy facies at the bottom of the section $1\left(\right.$ red $=$ layer $n^{\circ} 14$; blue $=$ layer $\left.n^{\circ} 15\right)$. One cannot see any river sorting.

\section{Conclusion}

The study of the lithostratigraphy of the ghost-rock in the two sections clearly indicates that we are not in the presence of a fluvial endokarstic filling but of a residual alterite. All facies depend on the nature of the initial unaltered rock. The weathering essentially affected the sandy limestone with thin shaly intercalations of the Hun Member. The higher initial permeability may guide the weathering solutions. Note however that the ghosting extends vertically in the Yvoir Formation following vertical joints. This setting is remarkable in that the alterite was preserved from mechanical erosion when the hydrodynamic potential increased following the Ardennes uplift and deepening of the Bocq valley through erosion.

This example is iconic because it proves that the first step of karstification, i.e. the isovolumetric weathering in the absence of a significant hydrodynamic potential, may affect the shape of a gallery. It forms a gallery, without any macroscopic void: we name it a "pseudogallery". We can see that the ghost-rock karstification creates shapes not only vertical corridors but also horizontal shapes which could become speleological galleries after the mechanical erosion of the residual alterite. This second evolution step will occur with the presence of a hydrodynamical potential.

\section{Acknowledgements}

The authors would like to thank the operators and staff of the Nutons quarry, as well as Prof. Jean-Marc Baele for the interpretation of the X-ray analyses and Ms Bérénice Deletter for the preparation of the samples and her assistance at the laboratory. The authors warmly thank the reviewers, Camille Ek, Richard Maire and Sophie Verheyden, for their constructive comments. They also thank Eddy Poty who let them know this very nice phenomenon. The authors would also like to thank the editor for the final proofreading work. 

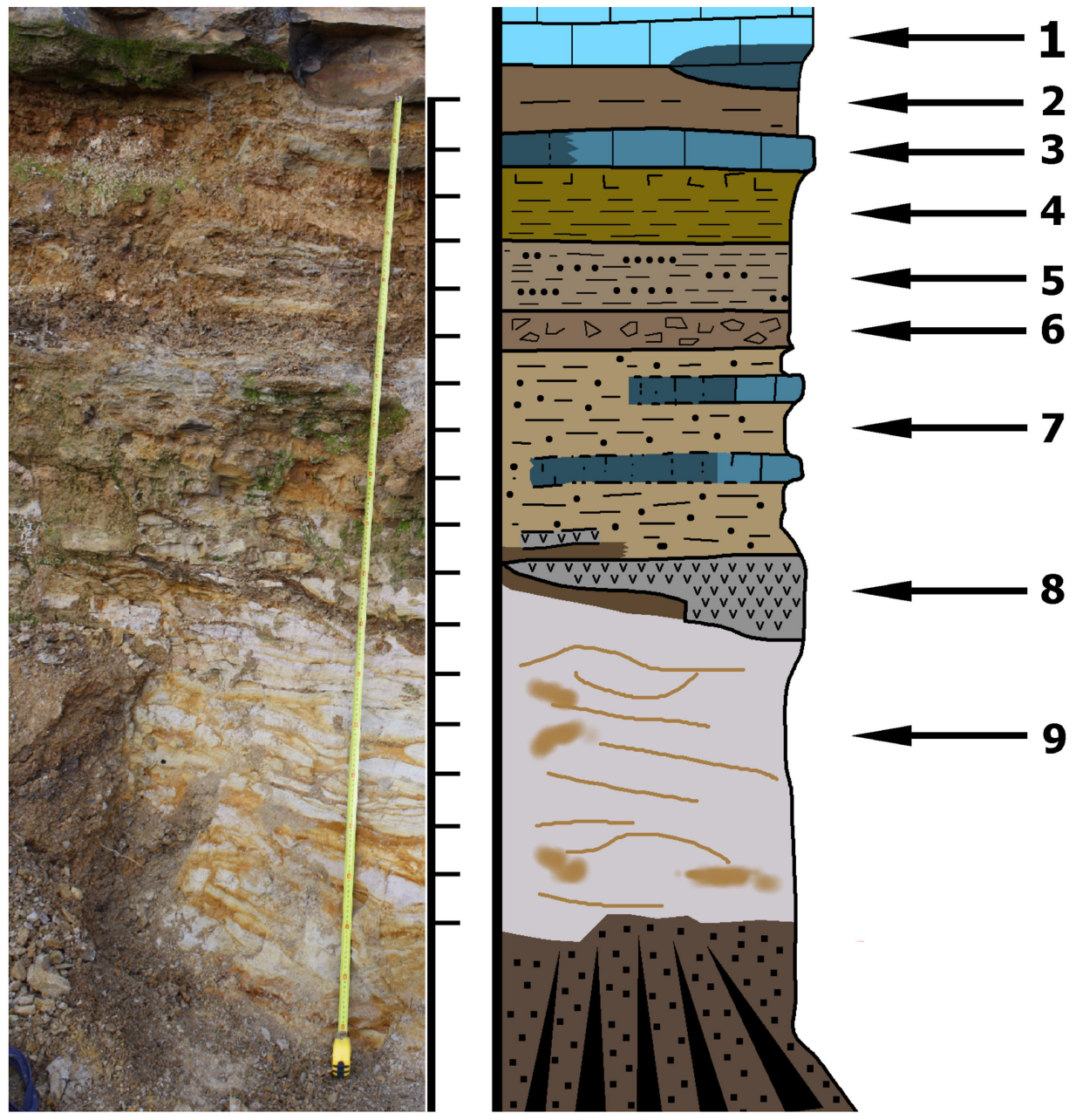

Figure 7. Lithology of section 2.

1. Partially ghosted limestone roof. 2. Loam grey, yellow to ochre. 3 . Still consistent stratum. 4. Compact yellow-brown clay, top with polyhedrons. 5. Brown clay and grey sands. 6. Prismatic brown clay. 7. Complex set with still consistent strata in grey sand and clay. 8. Tripoli. 9. Greyish white sandy beach with ochre-yellow areas.

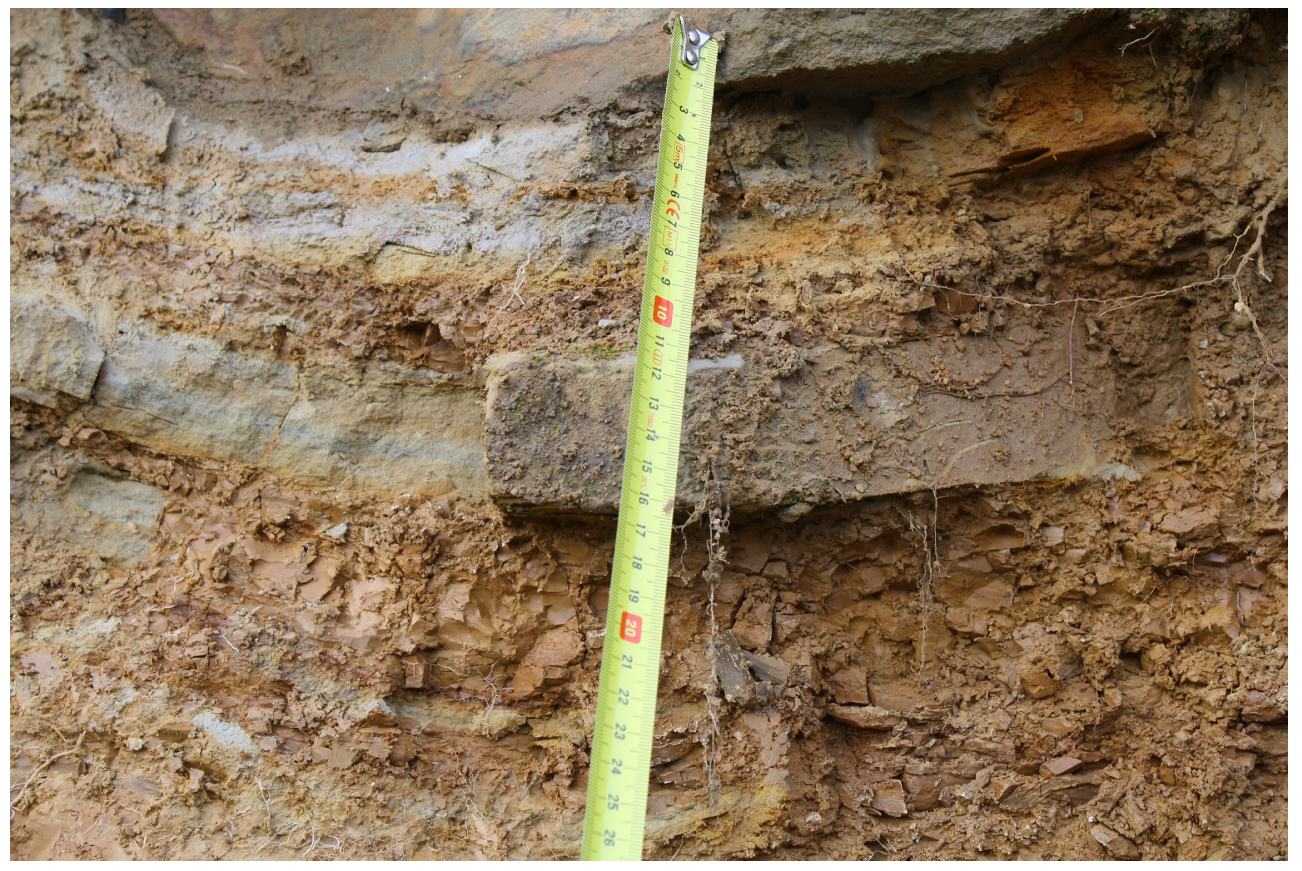

Figure 8. Transition from the bedrock on the right to the alterite on the left within the same stratum. 


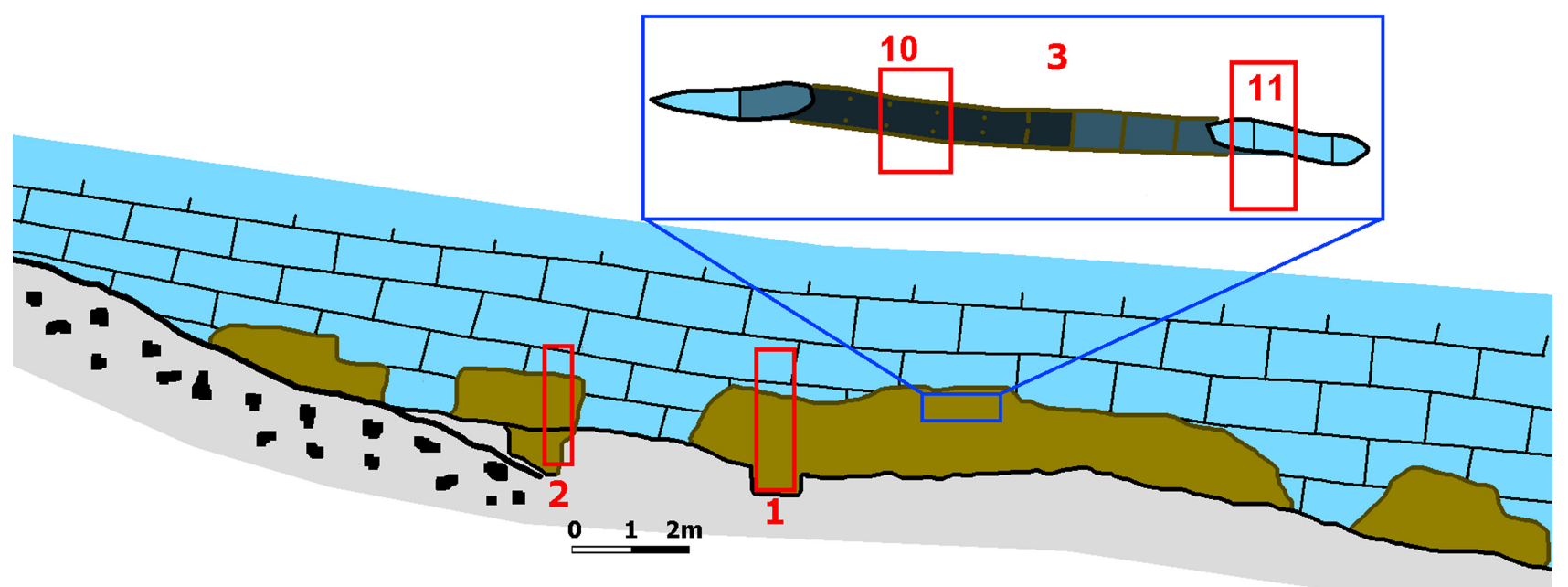

Figure 9. Location of the section 3 with the detail of the weathered stratum; view to the S. 1 and 2: location of the two first sections. 3: section 3. 10: weathered sample. 11: unaltered sample (see text).

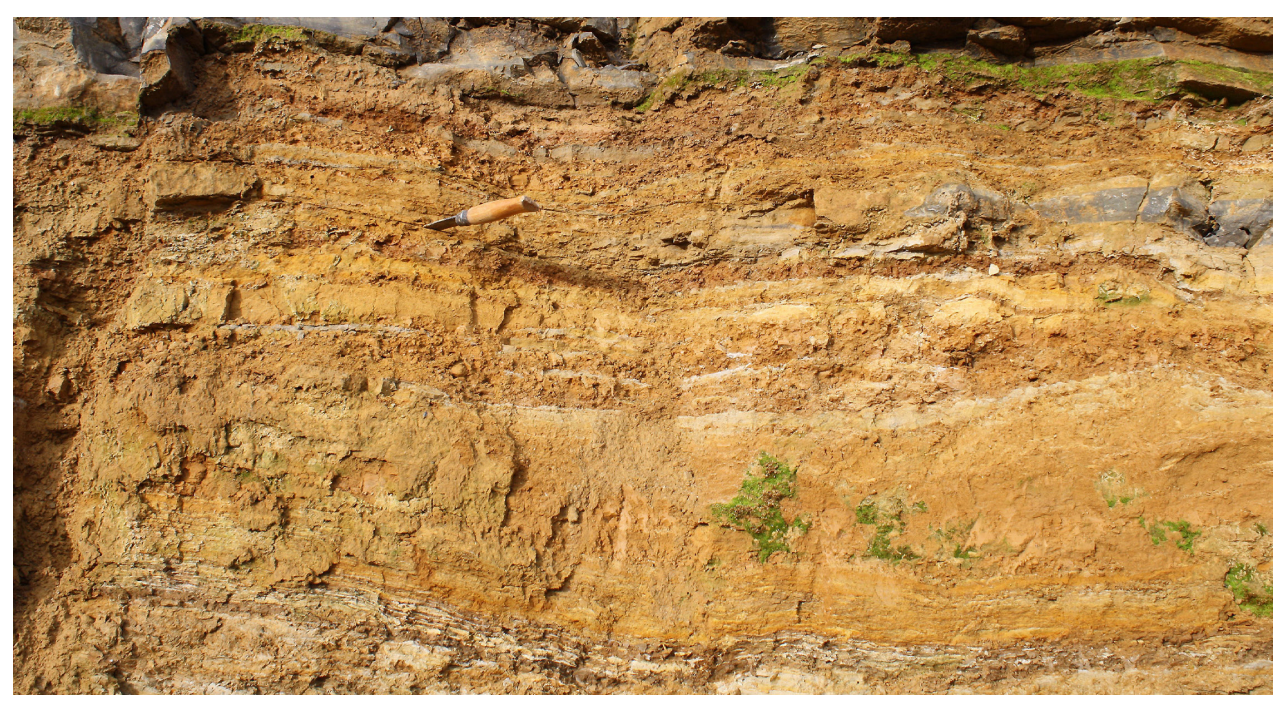

Figure 10. Section 3. The weathered stratum is underlined by two lines with a knife. This one gives the scale. On the right and on the left, we distinguish the parts much less affected by alteration, on the left in the form of a block in relief, on the right by a greyer colour. The section between these two extremes is totally altered, the knife enters easily.

Table 1. Results of the X-ray analysis on powders and of the calcimetry.

\begin{tabular}{|c|c|c|c|c|c|c|c|c|c|c|c|c|}
\hline RXPOWDER & NU01 & NU02 & NU03 & NU04a & NU04b & NU05 & NU07a & NU07b & NU08 & NU10 & NU11a & NU11b \\
\hline Quartz & 72.7 & 33.5 & 76.8 & 5.7 & 32.7 & 67.6 & 75.1 & 48.7 & 62.4 & 31.3 & 70.7 & 45.7 \\
\hline Calcite & 0.0 & 47.6 & 0.7 & 0.0 & 1.5 & 0.0 & 3.3 & 42.0 & 0.5 & 0.0 & 0.6 & 38.4 \\
\hline Clay & 27.3 & 18.9 & 22.6 & 94.3 & 65.8 & 32.4 & 21.5 & 9.3 & 37.2 & 68.7 & 28.7 & 15.9 \\
\hline Total & 100.00 & 100.00 & 100.00 & 100.00 & 100.00 & 100.00 & 100.00 & 100.00 & 100.00 & 100.00 & 100.00 & 100.00 \\
\hline
\end{tabular}

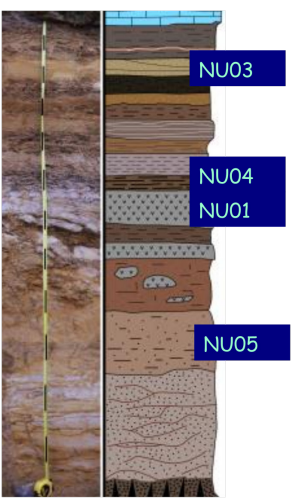

NU01 : tripoli.

NU02 : bedrock in the same stratum

than 1.

NU03 : sandy facies.

NU04a : brown clay.

NU04b : brown clay with white

inclusions.

NU05 : sandy facies.
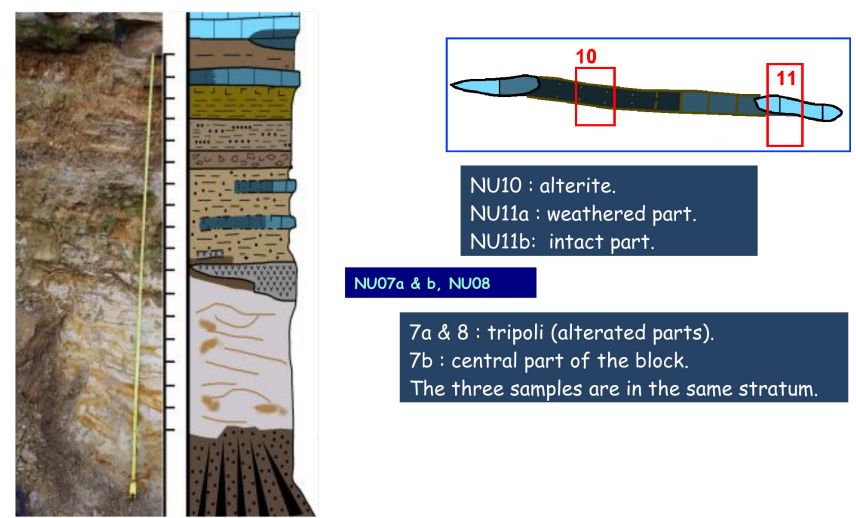

\begin{tabular}{lrrrrrrrrrr}
\hline CALCIMETRY & NU01 & NU02 & NU03 & NU04a & NU05 & NU06 & NU07a & NU07b & NU08 & NU10 \\
\hline Mean value & $<1$ & 34 & $<1$ & $<1$ & $<1$ & $<1$ & 2 & 36 & $<1$ & $<1$
\end{tabular} 


\section{References}

Delcambre, B. \& Pingot, J.-L., in press. Carte géologique de Wallonie : Bioul - Yvoir 53/3-4. 1/25 000. Namur, Service Public de Wallonie, avec une notice explicative.

Dubois, C., Quinif, Y., Baele, J.-M., Barriquand, L., Bini, A., Bruxelles, L., Dandurand, G., Havron, C., Kaufmann, O., Lans, B., Maire, R., Martin, J., Rodet, J., Rowberry, M.D., Tognini, P. \& Vergari, A., 2014. The process of ghost-rock karstification and its role in the formation of cave systems. Earth-Science Reviews, 131, 116-148. https://doi. org/10.1016/j.earscirev.2014.01.006

Havron, C., Baele, J.-M. \& Quinif, Y., 2007. Pétrographie d'une altérite résiduelle de type « fantôme de roche ». Karstologia, 49, 25-32.

Hennebert, M. \& Doremus, P., 1997. Carte géologique de Wallonie : Antoing - Leuze 37/7-8. 1/25 000. Namur, Ministère de la Région wallonne, Direction générale des ressources naturelles et de l'environnement, avec une notice explicative de $74 \mathrm{p}$.

Marion, J.-M. \& Barchy, L., in press. Carte géologique de Wallonie : Natoye-Ciney 54/1-2. 1/25 000. Namur, Service Public de Wallonie, avec une notice explicative.

Poty, E., Hance, L., Lees, A. \& Hennebert, M., 2001. Dinantian lithostratigraphic units (Belgium). In Bultynck, P. \& Dejonghe, L. (eds), Guide to a revised lithostratigraphic scale of Belgium. Geologica Belgica, 4/1-2, 69-94.

Poty, E., Aretz, M. \& Denayer, J. 2011. Field trip 3: Uppermost Devonian and Lower Carboniferous of Belgium. Kölner Forum für Geologie und Paläontologie, 20, 99-150.

Quinif, Y., 2010. Fantômes de roche et fantômisation - Essai sur un nouveau paradigme en karstogenèse. Karstologia Mémoires, 18, 196 p.

Quinif, Y., 2014. La fantômisation, une nouvelle façon de concevoir la formation des cavernes. Regards, 79, 42-72.

Quinif, Y., Baele, J.-M., Dubois, C., Havron, C., Kaufmann, O. \& Vergari, A., 2014. Fantômisation : un nouveau paradigme entre la théorie des deux phases de Davis et la théorie de la biorhexistasie d'Erhart. Geologica Belgica, 17/1, 66-74.

Quinif, Y., Vergari, A., Doremus, P., Hennebert, M. \& Charlet, J.-M., 1993. Phénomènes karstiques affectant le calcaire du Hainaut. Bulletin de la Société Belge de Géologie, 102, 379-394.

Rowberry, M., Dubois, C., Kaufmann, O., Baele, J.-M. \& Blahut, J., 2018. Weathering by dolomite dissolution responsible for the formation of an important palaeotological locality in the Prague synform. Acta Geodynynamica et Geomaterialia, 15/3, 297-309. https://doi. org/10.13168/AGG.2018.0022

Vergari, A., 1998. Nouveau regard sur la spéléogenèse : le "pseudoendokarst" du Tournaisis (Hainaut, Belgique). Karstologia, 31, 1218. 